\title{
Gaseous biofuels from waste: low environmental and toxicological impact with maximum benefit on the greenhouse effect
}

\author{
L. De Simio, M. Gambino \& S. Iannaccone \\ Istituto Motori, Italian National Research Council, Naples, Italy
}

\begin{abstract}
Biomethane, usable in existing natural gas engines, allows realization of vehicles with low environmental and toxicological impact, particularly suitable for urban area operation (fleets of cars, buses and trucks), also satisfying the incoming more stringent regulation limits.

On site biomethane production, through anaerobic digestion or future gasification-methanization plants, will allow the problem of gas distribution to be overcome when a natural gas grid is not widely diffused. The capture and use of biomethane derived from the organic waste matter decomposition process allows a significant reduction of greenhouse gas emissions into the atmosphere. Biogas production plants represent an attractive way, alternative to simple composting, to reduce organic material landfill disposal, as required by the European Union. With reference to dedicated crops, biomethane represents the most efficient method of biomass utilization in comparison with other biofuels in the first generation category. In any case, the same problems of land use competition (especially food in developing countries) can derive from the low conversion efficiency of solar energy in biomass. A better approach is given by the second generation for the capacity to use almost all the parts of the vegetables, leaving the edible fraction for food employment. For this category the best results could also be obtained with biomethane allowing consequent lower land use competition.

Improvements in hydrogen production from waste and biomass by dark fermentation and the connected possibility of direct production of methane/hydrogen mixtures could be another advantage thanks to the possibility of favouring gas engine development with higher efficiency and further decreasing emissions.
\end{abstract}

Keywords: biomethane, natural gas, greenhouse effect, waste, biomass. 


\section{Introduction}

The increasing costs and climate changing related to fossil fuels exploitation push interests towards alternative energetic sources. Among these the most attractive are the renewable ones because they are virtually inexhaustible and do not release $\mathrm{CO}_{2}$ into atmosphere. Recently great attention has been given to the use of biomass to produce fuels, especially for transport employment as an alternative to petrol. An important consideration is to be made for this proposal. Since biofuels definitely can be seen as a way to use solar energy, the low conversion efficiency of the global process has to be taken into account. In fact less than $1 \%$ of the solar energy is converted in biomass (from which are then obtained biofuels), and therefore the land for energy use is an enormous competitor with food production. From this consideration it is derived that dedicated energy crops are not a good way to solve the energetic and environmental issues. On the contrary biofuels production becomes extremely interesting when obtained from the waste or residuals of others human activities.

\section{Biomethane production}

Biogas is produced during the process of anaerobic fermentation (also called digestion) that consists of a biological breakdown of organic matter in the absence of oxygen activated by means of anaerobic micro organisms (bacteria). Biodegradable organic materials are converted into a mixture of methane $\left(\mathrm{CH}_{4}\right)$ and carbon dioxide $\left(\mathrm{CO}_{2}\right)$ with smaller amounts of hydrogen sulphide $\left(\mathrm{H}_{2} \mathrm{~S}\right)$. Traces of hydrogen $\left(\mathrm{H}_{2}\right)$, nitrogen $\left(\mathrm{N}_{2}\right)$, ammonia $\left(\mathrm{NH}_{3}\right)$, and oxygen $\left(\mathrm{O}_{2}\right)$ could be present in the biogas. Usually, the mixture is saturated with water vapour and may contain dust particles and siloxanes.

Table 1: $\quad$ Typical composition of biogas.

\begin{tabular}{|c|c|}
\hline Compound & Volumetric percentage, [\%] \\
\hline $\mathrm{CH}_{4}$ & $55 \div 70$ \\
\hline $\mathrm{CO}_{2}$ & $30 \div 45$ \\
\hline $\mathrm{H}_{2} \mathrm{~S}$ & $0.02 \div 0.2$ \\
\hline Water dew point & saturated \\
\hline $\mathrm{H}_{2}, \mathrm{NH}_{3}, \mathrm{O}_{2}, \mathrm{~N}_{2}$ & traces \\
\hline
\end{tabular}

Biogas proprieties independent of methane content are shown in figure 1 .

The biological decomposition of organic waste without oxygen is a process that occurs spontaneously in nature and in particular in old landfills at ambient temperature. Thus uncontrolled and open air landfills are responsible for biogas escape into the atmosphere. Since methane has a higher greenhouse effect than carbon dioxide (more than 20 times) capturing and burning $\mathrm{CH}_{4}$ from organic matter decomposition contributes to the reduction of global Earth warming. In controlled landfill it is possible to capture part of the biogas generated. The use of closed reactors (digesters), to product biogas, optimizing all factors involved in the biological processes (temperature, $\mathrm{pH}$, feedstocks, retention time in the 
system and solid content), leads to a higher yield of methane in biogas, drastically lowering escape into atmosphere. A certain amount of heat is necessary to keep the temperature at optimum levels in the digester. Heat is generated by burning part of produced biogas. In particular the share of biogas consumed for its production is usually around $25 \%$ in conventional plants.

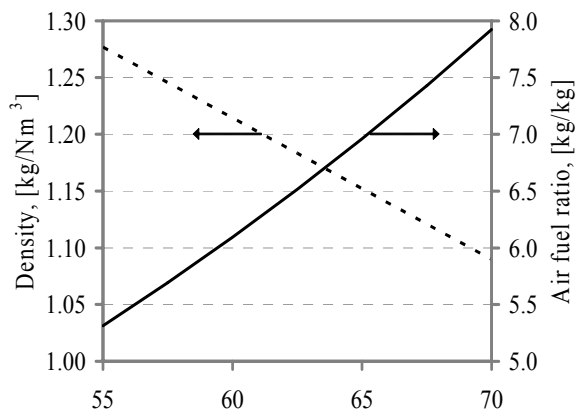

$\mathrm{CH}_{4}$ volumetric percentage in biogas, [\%]

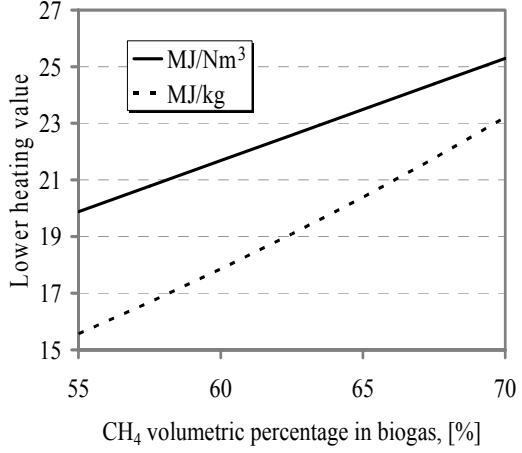

Figure 1: Biogas proprieties.

Feedstocks suitable for the production of biogas are all the putrescibles: biomass, manure or sewage, the organic fraction of municipal solid waste (MSW), and energy crops, taking into account that the higher the content of lignin the lower the amount of biogas obtainable. In table 2 the quantity of gas produced (after a couple of weeks in the digester) is reported from the anaerobic fermentation of different feedstocks. The biogas yield is expressed as a percentage by mass of dry or wet material.

Biogas can be directly utilized in combined heat and power (CHP) plants with the maximum efficiency in using the fuel.

Table 2: $\quad$ Biogas yields from some feedstocks (toe: tonnes of oil equivalent).

\begin{tabular}{|c|c|c|c|c|}
\hline Feedstock & $\begin{array}{l}\begin{array}{l}\text { Estimated } \\
\text { dry matter } \\
\text { content }\end{array} \\
(\%),[1]\end{array}$ & $\begin{array}{l}\text { Biogas Yield } \\
\text { (toe/dry } \\
\text { tonne), [1] } \\
1 \text { toe }=42 G J\end{array}$ & $\begin{array}{l}\text { Biogas Yield } \\
\text { (\% of feedstock } \\
\text { dry mass) } \\
\text { Lower heating } \\
\text { value } \cong 19 \mathrm{MJ} / \mathrm{kg}\end{array}$ & $\begin{array}{l}\text { Biogas } \\
\text { Yield } \\
\text { (\% of } \\
\text { feedstock } \\
\text { wet mass) }\end{array}$ \\
\hline $\begin{array}{l}\text { Manure } \\
\text { (cow-pig) }\end{array}$ & 8 & 0.16 & 35 & 3 \\
\hline Straw & 82 & 0.17 & 38 & 31 \\
\hline Slaughter waste & 17 & 0.23 & 51 & 9 \\
\hline $\begin{array}{l}\text { Tops and leaves } \\
\text { of sugar beet }\end{array}$ & 19 & 0.25 & 55 & 11 \\
\hline Ley crops & 23 & 0.25 & 55 & 13 \\
\hline $\begin{array}{l}\text { MSW, organic } \\
\text { fraction }\end{array}$ & 30 & 0.30 & 66 & 20 \\
\hline
\end{tabular}


When cogeneration is not practicable and only electric energy is produced, biogas upgrading to biomethane is the best alternative, allowing it to be used as a vehicle biofuel or to replace fossil natural gas (NG) in the existing network. The process increases the energy content by removing $\mathrm{CO}_{2}$, raising methane content, and meanwhile removes dust particles, $\mathrm{H}_{2} \mathrm{~S}$, siloxanes and other impurities to prevent pollution and formation of dangerous compounds during combustion. The energy cost necessary for the upgrading process is roughly $10 \%$ of the produced methane, estimated from the energetic consumptions necessary in the process [2].

When the technology for second generation biofuels production will become available it will also be possible to obtain biomethane from biomass gasification by methanation of syngas.

\section{Light duty natural gas engines}

Knowledge of the combustion of gaseous fuels allows both low emissions and comparable performance to gasoline with NG engines. NG can be used in after market or new vehicles, but the best results are obtained with dedicated engines.

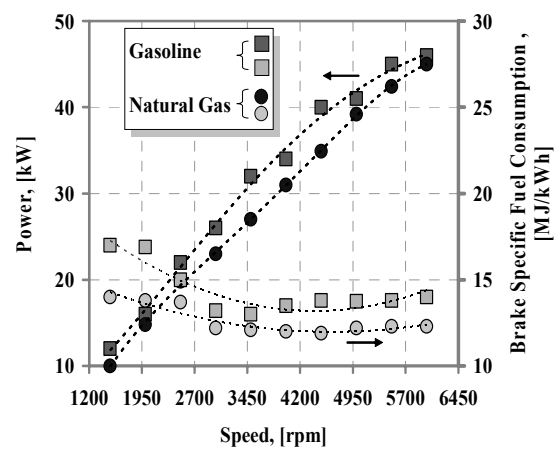

Figure 2: Comparison between the performance of a dedicated $\mathrm{NG}$ engine and a gasoline one, [3].

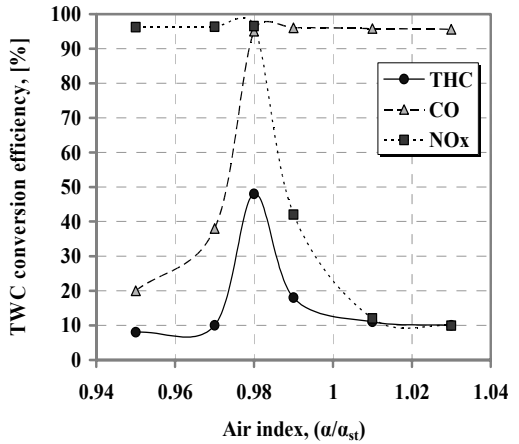

Figure 3: Conversion efficiency of a TWC (for gasoline cars) where the engine is fed with $\mathrm{NG},[4]$.

In fact in this case the physiological power decay due to the fuel gaseous state is overcome by changing the engine architecture. Power and fuel consumption of a conventional gasoline light duty engine and an optimized NG prototype developed in Istituto Motori are shown in figure 2. The same performance with higher efficiency was obtained with $\mathrm{NG}$, increasing spark advance, the volumetric compression ratio and inducing high turbulence levels by modifying the combustion chamber geometry. Nowadays cars designed for NG allow an integrated tank to be installed below the floor in order to increase the operative range without affecting luggage volume. Future turbocharged downsized engines 
with variable valve timing could permit higher efficiency, benefiting $\mathrm{CO}_{2}$ and NOx emissions.

With a bi-fuel after market NG application the loss of maximum power (due to the lower air trapped) generally occurs together with a decreasing of total unburned hydrocarbon (THC) conversion efficiency (figure 3). In fact the original catalyst of gasoline cars gives a low methane oxidation, which is the main compound of $\mathrm{THC}$ for the $\mathrm{NG}$ engine. This inconvenience is not present when a catalyst is optimized for methane conversion. However $\mathrm{CH}_{4}$ is not harmful for human health, even if it is a greenhouse gas. A bi-fuel NG vehicle can also run with gasoline, overcoming the constraints on operation range limitation.

Since fossil methane and biomethane are perfectly equivalent, the latter can be used with the same modality and the same characteristics of the fossil fuel.

\section{Heavy duty natural gas engines}

Heavy duty (HD) NG vehicles represent an optimal way for biomethane utilization in the transport sector. In fact, on board fuel tank allocation is less problematic than with light duty and the lack of a widespread fuel distribution network does not constitute a real constrain on their mission. Moreover they are employed especially in urban areas, where the population density is higher and therefore where there are greater environmental advantages deriving from their low emissions. The main characteristics of the HD lean burn (LB) NG engine developed in Istituto Motori for Florence city in 1992 are reported in table 3. It was derived from an IVECO 8460 Euro 0 diesel engine and modified for spark ignition operation in slightly lean condition.

Table 3: $\quad$ Main characteristics of NG SI heavy duty engine for Florence city public transportation (1992).

\begin{tabular}{ll}
\hline 6 cylinder in-line turbocharged & \\
Displacement & 9.51 \\
Bore x stroke & $120 \times 140 \mathrm{~mm}$ \\
Compression ratio & $9: 1$ \\
Combustion chamber & Bowl in piston \\
Rated power & $154 \mathrm{~kW} @ 2000 \mathrm{rpm}$ \\
Valve Overlap & $0^{\circ}$ \\
\hline
\end{tabular}

In addition to lower $\mathrm{NO}_{\mathrm{x}}$ and Particulate Matter (PM) emissions, a big decrease in toxicity was also found with $\mathrm{NG}$, as shown in table 4 . The $\mathrm{NG}$ toxicological index resulted about one order of magnitude lower than the corresponding diesel engine, even if formaldehyde resulted one order of magnitude higher for NG.

The engine was upgraded to a stoichiometric operation with a three way catalyst by changing the head, intake manifold and pistons, reaching a volumetric compression ratio of 10:1. Moreover an integrated electronic control 
was added (timed multi-point injection, one top plug coil for the cylinder, bywire throttling, and waste gate valve regulation). This engine was used to compare toxicity exhaust with the corresponding diesel version fuelled with diesel oil and a B20 blend (a $20 \% \mathrm{v} / \mathrm{v}$ of vegetable oil in diesel).

Table 4: Relative toxicity of unregulated emissions, on the base of unregulated compounds, which are included in Group 2A of IARC classification, measured on the 13 mode cycle, [5].

TLV-TWA

MAC

\section{Relative toxicity factor}

13 mode emission

CNG
DIESEL

Toxicity index

$\mathrm{CNG}$

DIESEL

\section{HCHO}

$1.5 \mathrm{mg} / \mathrm{m} 3$

1

$32.5 \mathrm{mg} / \mathrm{kWh}$

$3.8 \mathrm{mg} / \mathrm{kWh}$

\section{PAH*}

$0.00015 \mathrm{mg} / \mathrm{m} 3$

$10^{4}$

$0.00038 \mathrm{mg} / \mathrm{kWh}$
32.5

3.8
4

220

\section{Total index (HCHO+PAH*)}

CNG

DIESEL
36

224

*Benz(a)anthracene+Benzo(a)pyrene+Dibenz(a,h)anthracene.

Both regulated and unregulated emissions were largely lower for the stoichiometric NG engine. Natural gas mutagenicity is close to zero in comparison with diesel and B20 (figure 4). To reach a similar result with a diesel engine in addition to an electronic injection system with EGR, a more complex exhaust gas after treatment is necessary (continuous regenerating traps, oxidation catalyst and selective catalyst reduction ( $\mathrm{SCR}$ ) for $\mathrm{NO}_{\mathrm{x}}$ control).

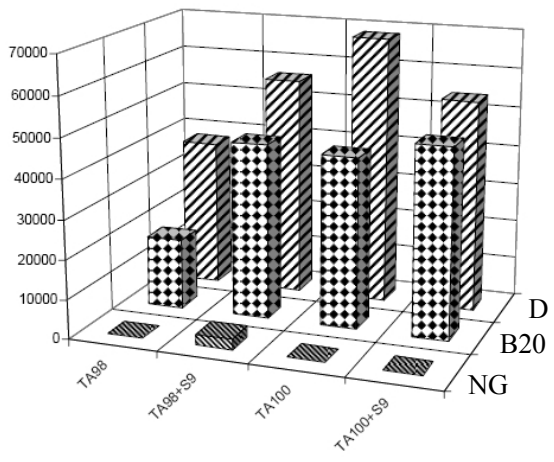

Figure 4: Mutagenicity of exhaust emissions from D (diesel), B20 (20\% biodiesel blend), and $\mathrm{NG}$ engine: induced revertants/kWh in S.typhimurium strains, [5]. 
For $\mathrm{NG}$ engines a further improvement of emission control is expected by optimizing the combustion phase. In Table 5 the target of NG near zero emission vehicles are reported. The provision is that they would comply with limits lower even than the most stringent EEV.

Table 5: $\quad$ Expected improvements on heavy duty NG engine emissions.

\begin{tabular}{llll}
\hline & $\begin{array}{l}\text { EEV limit [g/kWh] } \\
\text { Enhanced Environmentally } \\
\text { Vehicle }\end{array}$ & $\begin{array}{l}\text { NG NZEV } \\
\text { Near Zero Emission Vehicle }\end{array}$ & $\begin{array}{l}\text { NG NZEV } \\
\text { vs. } \\
\text { EEV }\end{array}$ \\
\hline PM & 0.02 & 0.01 & $-50 \%$ \\
$\mathrm{NO}_{\mathrm{x}}$ & 2.0 & 0.40 & $-80 \%$ \\
$\mathrm{THC}$ & 0.40 & 0.02 & $-95 \%$ \\
$\mathrm{CO}$ & 3.0 & 0.60 & $-80 \%$ \\
\hline
\end{tabular}

\section{Biomethane from waste}

The three major sources of organic waste are the organic wet fraction (almost $30 \%$ ) of MSW (roughly $1.5 \mathrm{~kg}$ per capita per day, in Europe), excrements and litter for cattle and residues originating from the food system. Regarding the last item, most of these residues are already currently used as cattle feed or as compost for cultivated land. In addition, they are often spread over vast areas for which it is difficult to organise an efficient conversion path into energy. For these reasons their employment would not be convenient for biofuel production [6].

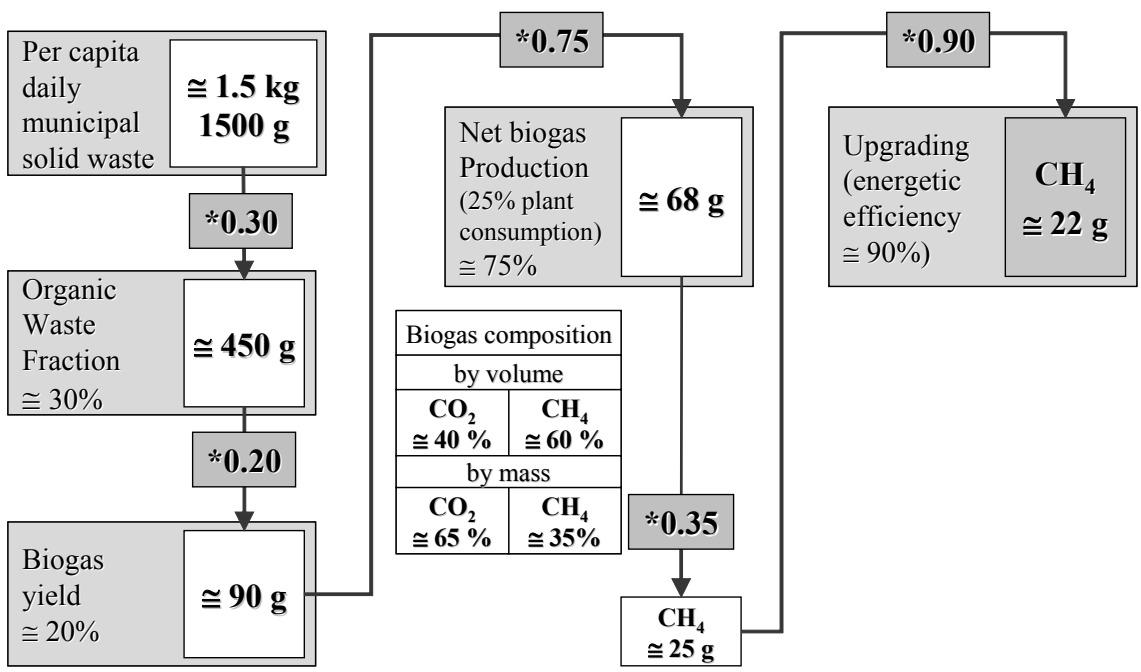

Figure 5: $\quad$ Per capita daily biomethane potential production from anaerobic fermentation of the wet organic wet fraction of MSW. 
The steps to estimate per capita daily biomethane potential production from $450 \mathrm{~g}$ wet organic fraction of MSW (1500g per capita daily) are shown in figure $5 ; 22 \mathrm{~g}$ of biomethane could be obtained every day from the waste produced by each person. Assuming that the typical fuel consumption of a CNG bus is almost $50 \mathrm{~kg} / 100 \mathrm{~km}$ (energetically equivalent to about $701 / 100 \mathrm{~km}$ of diesel oil), and that usually a bus travels $60000 \mathrm{~km} /$ year ( $\cong 170 \mathrm{~km} /$ day), gas consumption of a bus is almost $85 \mathrm{~kg} /$ day.

Usually, there is one bus (urban or suburban) for every 1000 people in urban areas, therefore the amount of biomethane produced from MSW, $22 \mathrm{~kg}$, can contribute $25 \%$ to the bus fuel consumption.

In other words with biomethane it will be possible to fill almost $25 \%$ of an urban (and suburban) bus fleet.

Biomethane from excrements and litter could raise this fraction to more than $50 \%$ since the energy source potential of them has proved to be the most important among the other residues in Europe, [8].

\subsection{Biohydrogen and biomethane mixtures from waste}

A future fuel for gas engine supply could be a mixture of methane and hydrogen with the last ranging from 10 to a maximum of $30 \%$ by volume, because of problems in the operating range due to the low density of hydrogen. The presence of hydrogen in the fuel accelerates the combustion process leading to small efficiency improvements, and to THC reduction, [9].

Anaerobic fermentation technologies will allow production of these mixtures directly from renewable sources. In fact biological hydrogen production from waste and biomass by dark fermentation can be coupled with anaerobic digestion to obtain biogas from residual products of the first phase [10]. The two phase process could be suited to obtain the optimum $\mathrm{H}_{2}-\mathrm{CH}_{4}$ mixture for engine supply.

\section{Biomethane from energy crops and its competitors}

By putting attention on biofuels produced from energy crops, they can be divided into two classes: the first and the second generation.

The first, achieved with technologies available today and already consolidated, requires different feedstock depending on the output product. Raw materials must also have a precise composition and often consist only of some parts of the plant, with food competition.

Second generation biofuels can be produced from almost all parts of the plant and in general from any lignocellulosic material. The potential offered by these fuels is very high, but the production technologies are still developing. In any case they generally avoid food competition when the sources are constituted of residual biomass.

\subsection{First generation biofuels}

Unlike when the raw material is a waste product, for dedicated energy crops it is not possible to ignore food competition and energy used in biomass 
production/harvest. For this reason, in addition to fuel yield per hectare it is necessary to consider the energy balance determined by the ratio between the total energy produced (stored in the fuel and byproducts) and the total energy input for the entire cycle of production. The main first generation biofuels, and the energy performance of the path way production are show in table 7. Among first generation biofuels, biomethane from maize appears to be the best energy performer.

Table 6: $\quad$ Main first generation biofuels [11, 12].

\begin{tabular}{|c|c|c|c|}
\hline & Biomethane & Bioethanol & Biodiesel \\
\hline $\begin{array}{l}\text { Biomass } \\
\text { feedstock } \\
\text { (dedicated crops) }\end{array}$ & $\begin{array}{l}\text { Sugar/cellulosic crops } \\
\text { (maize, grass...) }\end{array}$ & $\begin{array}{l}\text { Sugar/starch crops } \\
\text { (sugar beets/canes, } \\
\text { cereals...) }\end{array}$ & $\begin{array}{l}\text { Oil crops } \\
\text { (rape, sunflower, } \\
\text { palm...) }\end{array}$ \\
\hline $\begin{array}{l}\text { Production } \\
\text { process }\end{array}$ & $\begin{array}{l}\text { - anaerobic fermentation } \\
\text { - upgrading }\left(\mathrm{CO}_{2} \text { removal }\right)\end{array}$ & $\begin{array}{l}\text { - Hydrolysis } \\
\text { - Fermentation }\end{array}$ & $\begin{array}{l}\text { - Cold } \\
\text { pressing/extraction } \\
\text { - transesterification }\end{array}$ \\
\hline $\begin{array}{l}\text { Average } \\
\text { crop yields, }\end{array}$ & $\begin{array}{l}\text { From Maize: } \\
3000 \div 3600[\mathrm{~kg} / \mathrm{ha}]\end{array}$ & $\begin{array}{l}\text { From Wheat: } 26001 / \text { ha } \\
\text { From Sugar beets:(EU) } \\
55001 / \mathrm{ha} \\
\text { From Sugar } \\
\text { cane:(Brazil) }\end{array}$ & $\begin{array}{l}\text { From Rape: } \\
1200 \div 15001 / \text { ha } \\
\text { From Sunflower: } \\
1000 \div 12001 / \text { ha }\end{array}$ \\
\hline LHV & $49 \mathrm{MJ} / \mathrm{kg}$ & $21 \mathrm{MJ} / 1$ & $33 \mathrm{MJ} / 1$ \\
\hline Gross Energy & $\approx 160 \mathrm{GJ} / \mathrm{ha}$ & $\approx 110 \mathrm{GJ} / \mathrm{ha}(\mathrm{EU})$ & $\approx 50 \mathrm{GJ} / \mathrm{ha}$ \\
\hline Energy Balance & $3: 1$ & $2: 1$ & $3: 1$ \\
\hline Net Energy & $\approx 100 \mathrm{GJ} / \mathrm{ha}$ & $\approx 50 \mathrm{GJ} / \mathrm{ha}(\mathrm{EU})$ & $\approx 30 \mathrm{GJ} / \mathrm{ha}$ \\
\hline
\end{tabular}

\subsection{Second generation biofuels}

In the future, for a large production of second generation biofuels, waste or agroforestry residues will be used as feedstock as well as lignocellulosic material derived from dedicated short rotation forestry crops.

Also among the second generation, biomethane appears to be the best energy performer (minimum land use competition) (table 8).

Table 7: Main second generation biofuels from lignocellulosic material [13-15].

\begin{tabular}{|c|c|c|c|}
\hline & Biomethane & Bioethanol & Biodiesel \\
\hline $\begin{array}{l}\text { Production } \\
\text { process }\end{array}$ & $\begin{array}{l}\text { - Gasification (Syngas: } \\
\left.\mathrm{H}_{2}, \mathrm{CO}, \mathrm{CO}_{2}, \mathrm{CH}_{4}\right) \\
\text { - Methanation } \\
\text { - Fuel conditioning }\left(\mathrm{H}_{2} \mathrm{O} \text {, }\right. \\
\mathrm{CO}_{2} \text { removal) }\end{array}$ & $\begin{array}{l}\text { - Advanced Hydrolysis } \\
\text { - Fermentation }\end{array}$ & $\begin{array}{l}\text { Gasification } \\
\text { - Synthesis } \\
\text { - Fuel conditioning } \\
\text { (Separator, } \\
\text { hydrocraker) }\end{array}$ \\
\hline $\begin{array}{l}\eta=(\text { Output } \\
\text { energy/Feedstock } \\
\text { energy) }\end{array}$ & $\eta \approx 60 \div 70 \%$ & $\begin{array}{l}\eta \approx 40 \% \\
(+\approx 30 \% \text { lignin })\end{array}$ & $\begin{array}{l}\eta \approx 40 \div 55 \% \\
\text { Biomethane } \\
\text { co-production: } \\
\eta_{\text {biomethane }} \approx 5 \div 30 \% \\
\eta_{\text {biodiesel }} \approx 55 \div 40 \% \\
\eta_{\text {global }} \approx 60 \div 70 \%\end{array}$ \\
\hline
\end{tabular}




\section{Conclusion}

Very high benefits are connected to the biofuels produced by feedstock coming from waste or residuals. The convenience with dedicated crops is not so clear, due to the low conversion efficiency of solar energy in biomass that limits the maximum efficiency in the energy balance. In any case biomethane represents the most efficient way to convert biomass into biofuels, both from waste or energy crops, either for the first or second generation.

Utilization of putrescible matter in biomethane production and associated compost as a byproduct through anaerobic fermentation in a digester allows a reduction of organic waste landfill disposal and therefore a significant decrease in greenhouse gas emissions into the atmosphere. Future improvements in anaerobic plants will allow $\mathrm{H}_{2} / \mathrm{CH}_{4}$ mixtures to be obtained directly from organic waste.

Biomethane, being perfectly equivalent to fossil $\mathrm{NG}$, can replace it in the distribution network. Therefore it can be employed in any application field (domestic, industrial and transport). In particular it can be used in light duty and heavy duty vehicles with minimum environmental and toxicological impact, especially suitable in crowded urban areas. Moreover local biomethane production offers the possibility of placing refuelling stations independently from a NG grid.

\section{References}

[1] Eriksson, P., Olsson, M., The Potential of Biogas as Vehicle Fuel in Europe, Göteborg, Sweden, Report No. 2007:6, ISSN: 1404-8167, 2007.

[2] Jönsson, O., Persson, M., Biogas as transportation fuel, Swedish Gas Centre, FVS Fachtagung, 2003.

[3] Gambino, M., Iannaccone, S., Unich, A., L'impiego della marmitta catalitica su vetture alimentate a metano, Congresso Esposizione Internazionale sul'Impiego del Metano nei Trasporti, pp. 114-125 Bologna, 1990.

[4] Gambino, M., Iannaccone, S., Unich, A., Tecnologia costruttiva per una specifica motorizzazione a metano, Congresso Esposizione Internazionale sul'Impiego del Metano nei Trasporti, pp. 126-135 Bologna, 1990.

[5] Baldassarri, L.T., Battistelli, C. L., Conti, R., Crebelli, R., De Berardis, B., Iamiceli, A. L., Gambino, M., Iannaccone, S., Evaluation of emission toxicity of urban bus engines: Compressed natural gas and comparison with liquid fuels", Elsevier 2004.

[6] De Simio, L., Gambino, M., Iannaccone, S., Influence of swirl on performance and emissions of natural gas heavy duty engines, EAEC 2007, 11th European automotive congress, Budapest, 2007.

[7] Nonhebel, S., Energy from agricultural residues and consequences for land requirements for food production, Agricultural Systems 94 pp. 586-592, Elsevier 2007. 
[8] Kaltschmitt, M., Thrän, D., Weber, M., Scheuermann, A., Fröhlich, N., Thoroe, C., Schweinle, J., Zeddies, J., Henze, A., Fritsche, U.R., Jenseit, W., Rausch, L. Schmidt, K., Sustainable strategies for biomass use in the European context, Institut für Energetik und Umwelt gGmbH (IE), Leipzig (Germany), 2006.

[9] Dimopoulos, P., Boulouchos, K., Rechsteiner, C., Soltic, P., Hotz, R., Combustion Characteristics of Hydrogen-Natural Gas Mixtures in Passenger Car Engines, Sae, 2007

[10] Manish, S., Banerjee, R., Comparison of biohydrogen production processes, Elsevier 2007.

[11] Rutz, D., Jassen, R., Biofuel technology handbook, WIP Renewable Energies, 2007

[12] Paul, N., Kemnitz, D., Biofuels, FNR, 2006

[13] Boerrigter, H., Zwart, R.W.R., High efficiency co-production of FischerTropsch transportation fuel and substitute Natural Gas from biomass, ECN Biomass, 2004

[14] Drift, A., Meijden, C.M., Boerrigter, H.: Milena gasification technology for high efficient SNG production from biomass, ECN Biomass 2005, 14th European Biomass Conference \& Exhibition, Paris France, 2005

[15] Tampier, M., Beauchemin, P. A., Smith, D., Bibeau, E., Identifying Environmentally Preferable Uses For Biomass Resources, British Columbia Ministry of Forests and Range, Ministry of Energy, Mines \& Petroleum Resources, 2006 